\title{
Joseph MARGOLIS, Three Paradoxes of Personhood: The
} Venetian Lectures

Hermann, Mimesis International, 2017, 146 pages

\section{Matthias Kramm}

\section{(2) OpenEdition}

\section{Journals}

Electronic version

URL: http://journals.openedition.org/ejpap/1195

DOI: 10.4000/ejpap.1195

ISSN: 2036-4091

Publisher

Associazione Pragma

\section{Electronic reference}

Matthias Kramm, "Joseph margolıs, Three Paradoxes of Personhood: The Venetian Lectures ", European Journal of Pragmatism and American Philosophy [Online], X-1 | 2018, Online since 20 July 2018,

connection on 24 September 2020. URL : http://journals.openedition.org/ejpap/1195 ; DOI : https:// doi.org/10.4000/ejpap. 1195

This text was automatically generated on 24 September 2020.

\section{(c) (i) $\odot$}

Author retains copyright and grants the European Journal of Pragmatism and American Philosophy right of first publication with the work simultaneously licensed under a Creative Commons AttributionNonCommercial-NoDerivatives 4.0 International License. 


\title{
Joseph MARGOLIS, Three Paradoxes of Personhood: The Venetian Lectures
}

Hermann, Mimesis International, 2017, 146 pages

\author{
Matthias Kramm
}

\section{REFERENCES}

Joseph MARgolis, Three Paradoxes of Personhood: The Venetian Lectures, Hermann, Mimesis International, 2017, 146 pages

1 In the academic world, Joseph Margolis is best known as the proponent of a particular combination of radical historicism and robust relativism. In his publications, he argues that "humankind is the measure of all things" with regard to aesthetics, history, natural and social sciences, and philosophy. In doing so, he effortlessly interacts with authors from the continental, pragmatist, and analytic traditions. His book Three Paradoxes of Personhood is a collection of the three Venetian lectures and the Michael Eldridge Lecture which Margolis was invited to give at Ca' Foscari University of Venice. These highly thought-provoking contributions should be of particular interest to pragmatist scholars working in the areas of anthropology, philosophy of language, social ontology, and political philosophy.

2 The book begins with an excellent and very accessible introduction to the philosophy of Joseph Margolis by Roberta Dreon, which familiarises the uninitiated reader with key themes from his work. This introduction is followed by Margolis's three Venetian lectures, which make up the bulk of the book, and then by his Michael Eldridge Lecture. The two sketches by Jale N. Erzen that supplement the text convey a vivid picture of the pragmatist philosopher at work as a thinker and as a speaker.

Dreon's introduction to Margolis's philosophy puts a particular emphasis on his aesthetic work, but also includes an outline of his relativism, his constructivism, and his historicism. In addition, Dreon provides a very helpful overview of the reception of Margolis's philosophy in Italy, which forms the background to his Venetian lectures. By 
acquainting the reader with Margolis's (sometimes idiosyncratic) conceptual framework, she makes the text approachable for a wider audience. Of particular interest are the connections she draws between Margolis's writings and the classical pragmatists - for example, his development of Dewey's concept of the human being as a cultural animal.

Margolis's four lectures are structured around three paradoxes. I will first describe these three paradoxes which form the leitmotif of his first three lectures, then provide some comment on the three lectures in turn, before ending with some notes on the Michael Eldridge Lecture, which can be read as a conclusion to the foregoing argument and as an application of its results to political philosophy. When Margolis writes about a paradox, he diverges from the standard definition of the term. Instead, he refers to a philosophical puzzle which refuses a solution within one particular philosophical paradigm, but which requires a combination of two or more approaches that may stand in considerable tension with each other.

The paradox Margolis addresses in his first lecture concerns the transformation of human primates into persons. Neither a purely Darwinist nor a purely intellectualist approach can account for this problem. Thus, Margolis demands a revision on both sides in order to conceptualise human beings as hybrid creatures that mingle "biologically and culturally acquired abilities" (p. 41). While evolution can explain the development of prelinguistic conceptual abilities, it is only through the active use of language that consciousness can arise. The paradox of the second lecture deals with the vagueness and indeterminacy of our language, something Margolis terms as "mongrel functionality" (63). Both a rationalist reconstruction of human language and a therapeutic treatment of possible conceptual confusions are at a loss here. According to Margolis, mongrel devices fulfil a certain function within our language, in both its philosophical and its non-philosophical varieties. They help us to signal conceptual puzzles which we cannot yet solve, and to avoid absurd phrasings. The third lecture analyses the collective nature of enlanguaged societies and the question of whether society is based on mutual understanding or whether meaning is based on societal conventions. Margolis rejects both the notion of society as a mere aggregation of competent speakers and the intellectualist notion of meaning as independent of any form of collective life. Instead, he reinterprets Wittgenstein's concept of the Lebensform (form of life) in order to describe the mastery of language as "the very paradigm of a collective practice" (123) in which the meaning of our utterances is rooted. Thus, we can trace the meaning of our words back to this collective practice, but this is where we reach bedrock.

6 Having outlined the themes of the three lectures, I will now consider each lecture in turn in order to locate those themes in the dialogue between Margolis and his various conversation partners and to identify common threads, such as Margolis's continued criticism of a rationalist version of pragmatism which he refers to as The Pittsburgh School (naming in particular Wilfrid Sellars and Robert Brandom). Afterwards, I will connect these themes and threads with Margolis's Michael Eldridge Lecture.

7 In his first lecture, "Persons as Natural Artifacts," Margolis engages with (among many others) Michael Tomasello on the one hand, and Brandom on the other. He applauds Tomasello for recognising the crucial role of language in human development but criticises him for disregarding the continuities between human animals and nonhuman animals. Interestingly, he discovers a precursor of this confusion about the 
continuity between prelinguistic and linguistic capacities in George Herbert Mead. While Tomasello attributes we-intentionality to human beings, Margolis sees this capacity already present in non-human animals. We can attribute perceptual and nonlinguistic concepts to animals, whereas discursive concepts are restricted to the human realm. Thus, the solution to the first paradox is a concept of the human person as an "artifactual transform" (54) of the human primate which presupposes prelinguistic conceptual capacities on the part of non-human animals. Margolis contrasts this continuity thesis with Brandom's inferentialism, which he interprets as proposing an alternative solution to the problem. According to Margolis, Brandom establishes the rational autonomy of our framework of reasoning and, consequently, avoids any reference to nonlinguistic concepts in his explanation of human rationality. Yet, his supposed rational autonomy remains merely heuristic and "effectively unsecured" (57).

8 Margolis's primary conversation partners in his second lecture on "The Mongrel Functionality of Ordinary Language" are Noam Chomsky and Ludwig Wittgenstein. Margolis acknowledges Chomsky's contributions to the specification of the biological resources necessary for the development of language. Yet, he is profoundly critical of Chomsky's reconstruction of universal grammar, because it ignores the import of both evolutionary and cultural history. Chomsky attempts to reduce the variety of natural languages to a common underlying formula, whereas Wittgenstein claims the opposite: that language cannot and should not be reduced in this way. But Margolis is not satisfied with Wittgenstein's therapeutic project of dissolving conceptual confusions either. He takes the famous example of the mind/body puzzle and analyses the different ways in which it has been treated by Descartes and Kant. According to Margolis, our language can assume a mongrel function of remaining deliberately vague on conceptual issues and keeping the conversation open to further specification. Thus, neither Descartes's dualism nor Kant's apperceptive unity solve the conceptual problem of the relationship between body and mind, but they provide a "reassuring picture" (91) which helps us to continue to use these two concepts both in philosophical and non-philosophical language. Descartes's and Kant's concepts function as temporary placeholders.

In the third lecture, on "Collective Individuals," Margolis again engages with a great diversity of authors, but the two who stand out are Charles S. Peirce and Vincent Descombes. He discovers in Peirce's Collected Papers a first move away from an understanding of society as a mere aggregation of individuals to society as a collective unit. In his article "What Pragmatism Is," Peirce describes society as a "loosely compacted person" (114). Descombes adds an additional layer of complexity to the underlying philosophical problem: he sees an incoherence between employing the concept of society to refer to a collection of individuals and using it to refer to an individual of a superior order. Margolis disagrees with Descombes's verdict. He suggests resorting to the mongrel functionality of language in order to do justice to the collective features that can be attributed to enlanguaged societies. While speech must be ascribed to individual persons, meaning goes beyond the individual and involves the collective. Accordingly, Margolis suggests a reinterpretation of the Wittgensteinian notion of Lebensform as "the nominalized totality of all the continually evolving processes (and all the contexts enabling the processes) of external and internal Bildung, 
that transform human primates into persons and issue in whatever human societies thereupon do, produce, utter, enact, bring about, and Intentionally manifest" (99).

I come now to Margolis's Michael Eldridge Lecture, which bears the title "Norms Misjudged." The topic of this lecture is the interpretation of societal norms and the question of whether they can be justified or universalised. In this lecture, Brandom's inferentialism is not explicitly mentioned, but Margolis engages critically with the Kantian enterprise which leads him to polemicise against The Pittsburgh School as one of many "regressive revivals of rationalism" (127). Margolis begins this lecture by arguing that Kant's notion of transcendental necessity cannot be upheld in the face of the history of physics. He concludes from this that Kant's application of a regulative principle in the realm of politics and morals is endangered as well. At this point, Margolis begins a conversation with John Rawls and Jürgen Habermas, whom he regards as "the leading Kantian-inclined moral-political philosophers of the twentieth century" (130), in order to provide philosophical evidence for his argument. Comparing the late Rawls of The Law of Peoples with the early Rawls of A Theory of Justice, he sees Rawls as retreating from an abstract moral universalism to the "contingencies of ethical practice" (133) and to the non-universalisable requirements of his liberal proposal. In Habermas, Margolis senses a deep incompatibility between the naturalised transcendentalism of his discourse theory and the pragmatist manner in which he reconstructs rational consensus. Margolis consequently suggests that transcendental rationalism and methodological individualism must be abandoned, and, with them, the notion of absolute moral norms. Instead, we should rely on cultural memory, contemporary ideals, future hope, and reasonable inquiries in order to construct a " modus vivendi [...] among aggregated persons and collective peoples, among all the diverse societies of our age" (140). Returning to the title of his lecture, Margolis rejects any claim of a priority between moral norms and ethical values.

11 In sum, Margolis's Three Paradoxes of Personhood provides an impressive and exemplary intellectual masterclass in thinking through the issues of personhood, language, society, and social norms as radically historical and contingent categories. The emergence of personhood is contingent upon prelinguistic conceptual abilities, language retains the vagueness and indeterminacy it acquired in the evolutionary adaptation of human beings to changing environments, enlanguaged societies are imbedded in contingent forms of life, and social norms can only be substantiated by resorting to existing cultural practices. At the same time, all four categories are the result of hybrid processes in which biological and cultural factors are intertwined. Margolis's argument acquires its extraordinary force from his dialectical engagement with a multiplicity of conversation partners. By indicating the shortcomings of two opposite approaches, Margolis creates space for a third option. He also puts considerable effort into clarifying what pragmatism is and what it is not. Thus, he defends the pragmatist thesis of continuity between nature and culture against Brandom's inferentialism, which he interprets as a rationalist counter-proposal to pragmatism. Although Margolis's defence need not be the last word in this debate, it nevertheless provides a very useful starting point for further discussions.

12 That said, Margolis's great ability to engage with other philosophers can sometimes make it difficult to follow his argument, as it is mainly developed in conversation with other points of view. While this discursive style enriches his argument considerably, it occasionally comes at the expense of stringency and clarity. And while he provides a 
fair treatment of his discussants in the first three lectures, I am a bit hesitant about his analysis of Rawls's and Habermas's shortcomings. By reducing the tensions in their philosophical work too much to metaethical considerations, he does not take sufficiently into account their political and moral thought, neglecting, for example, that Rawls's "overlapping consensus" is also based on political reasons. A third and final point concerns a question regarding the mongrel functionality of language in the philosophical realm: While Margolis rightly points to the usefulness of mongrel devices in keeping philosophical conversations open to future corrections and specifications, I would have liked to know more about the way in which such criticism and corrections can and should take place - for example, with regard to Cartesian mind/body dualism.

\section{AUTHORS}

\section{MATTHIAS KRAMM}

Utrecht University

m.kramm[at]uu.nl 